\title{
recA mutations reduce adherence and colonization by classical and El Tor strains of Vibrio cholerae
}

\author{
K. Krishna Kumar, ${ }^{1}$ Ranjana Srivastava, ${ }^{1}$ V. B. Sinha, ${ }^{1}$ Jane Michalski, ${ }^{2}$ \\ James B. Kaper ${ }^{2}$ and Brahm S. Srivastava'
}

Author for correspondence: Brahm S. Srivastava. Tel: +91522 232411. Fax: +91522 243405.

\author{
1 Division of Microbial \\ Genetics, Central Drug \\ Research Institute, \\ Lucknow 226001, India \\ 2 Center for Vaccine \\ Development, University of \\ Maryland, School of \\ Medicine, Baltimore, \\ MD 21201, USA
}

\begin{abstract}
Two recA mutants of Vibrio cholerae (classical and EI Tor biotypes) were constructed by disruption of the wild-type recA gene with mutated recA sequences of $V$. cholerae cloned in the suicide vector pGP704. Mutants defective in the recA gene were compared with their respective RecA ${ }^{+}$parent strains with regard to their adherence to isolated rabbit intestine and colonization of intestine of infant mice. The recA mutation in $V$. cholerae was found to diminish adherence and markedly affected colonization.
\end{abstract}

Keywords: Vibrio cholerae, $\operatorname{rec} A$, adherence, colonization

\section{INTRODUCTION}

Vibrio cholerae O1 causes cholera, a diarrhoeal disease of man. After oral ingestion, bacteria enter the lumen of the gut where adherence to and colonization of intestinal epithelium occurs followed by secretion of cholera enterotoxin. It was reported several years ago that $V$. cholerae have a $\operatorname{rec} A$ system analogous to that of Escherichia coli (Ghosh et al., 1985). Subsequently, the $\operatorname{rec} A$ gene of $V$. cholerae was cloned and shown to complement an E. coli rec $A$ mutant (Goldberg \& Mekalanos, 1986a; Paul et al., 1986). It was further shown that duplication and amplification of the cholera toxin gene was RecAdependent (Goldberg \& Mekalanos, 1986b). In volunteer studies, $\operatorname{rec} A$ derivatives of a $V$. cholerae vaccine strain were found to show diminished immunogenicity (Ketley et al., 1990). Since adherence and colonization are important virulence characteristics of $V$. cholerae, it prompted us to construct $\operatorname{rec} A$ mutants of classical and $\mathrm{El}$ Tor biotypes and to study the effect of the mutation on adherence and colonization of vibrios in experimental animals.

\section{METHODS}

Media and buffer. Bacteria (Table 1) were routinely grown in L-broth (pH 6.5) containing tryptone (10 g), yeast extract $(5 \mathrm{~g})$ and $\mathrm{NaCl}(5 \mathrm{~g})$ in 1 litre distilled water. For plates, L-broth was solidified with $1 \cdot 2 \%(\mathrm{w} / \mathrm{v})$ agar. All dilutions were made in phosphate-buffered saline (PBS; $1.21 \mathrm{~g} \mathrm{~K}_{2} \mathrm{HPO}_{4} \mathrm{l}^{-1}, 0.34 \mathrm{~g}$ $\mathrm{KH}_{2} \mathrm{PO}_{4} \mathrm{l}^{-1}, 8 \cdot 0 \mathrm{~g} \mathrm{NaCl} \mathrm{l}^{-1}, \mathrm{pH} \mathrm{7 \cdot 3)}$. Filter-sterilized solutions

Abbreviation: MMS, methyl methanesulphonate. of ampicillin (Ap) and streptomycin ( $\mathrm{Sm}$ ) were added, when required, at $50 \mu \mathrm{g} \mathrm{ml} \mathrm{m}^{-1}$.

Construction of recA mutants. Ketley et al. (1990) reported the cloning of an approximately $7 \mathrm{~kb}$ EcoRI DNA fragment that contained the $\operatorname{rec} A$ gene of $V$. cholerae $\mathrm{O} 1$ strain 569B. A frameshift mutation was constructed in this $\operatorname{rec} A$ gene by ligation of an 8 bp synthetic oligonucleotide containing the restriction site $K p n I$ and the plasmid containing the mutant gene was designated pCVD842 (Ketley et al., 1990). The $7 \mathrm{~kb}$ EcoRI fragment containing the mutagenized sequence from pCVD842 was purified and ligated into the EcoRI site of the suicide vector pGP704 (Miller \& Mekalanos, 1988) to generate plasmid pCVD845. pGP704 replicates only when its deficient R6K origin is complemented in trans by the pir function contained in the $\lambda$ phage integrated in the chromosome of E. coli SM10 $\lambda$ pir (Kolter et al., 1978). This strain also contains the transfer genes of the broad host range plasmid RP4 integrated in its chromosome which allows mobilization of the suicide vector or its derivative pCVD845 (Simon et al., 1983). Thus pCVD845 was stably maintained in strain SM10 ipir and conjugally transferred into $V$. cholerae strains KB207 and CD81. Since pCVD845 cannot replicate autonomously in $V$. cholerae, recombination with homologous chromosomal DNA can occur, thereby generating $r e c . A$-deficient derivatives. $V$. cholerae strains KB207 and CD81 were grown in L-broth and mated with E. coli SM10 $\lambda$ pir(pCVD845) grown in L-broth containing ampicillin by mixing $4 \mathrm{ml}$ of the donor and $6 \mathrm{ml}$ of the recipient strains and filtering them through a $0.22 \mu \mathrm{m}$ membrane filter. The membrane was then placed on L-agar and incubated overnight at $37^{\circ} \mathrm{C}$. The mating mixture was resuspended in L-broth and plated on ampicillin- and streptomycin-containing agar plates to allow growth of recombinant bacteria. Colonies were tested for the $\operatorname{rec} A$ mutant phenotype by assessing their sensitivity to UV light and methyl methanesulphonate (MMS). Individual colonies were suspended in a drop of PBS and replica-spotted on two L-agar plates. One plate was exposed to a UV dose that did 
Table 1. Bacterial strains and plasmids

\begin{tabular}{|c|c|c|}
\hline $\begin{array}{l}\text { Strain or } \\
\text { plasmid }\end{array}$ & Description & Reference or source \\
\hline \multicolumn{3}{|l|}{$V$. cholerae } \\
\hline $\mathrm{KB} 207$ & El Tor, $\mathrm{Sm}^{\mathrm{r}}$ & $\begin{array}{l}\text { Srivastava \& Srivastava } \\
(1980)\end{array}$ \\
\hline $\mathrm{CD} 81$ & $\begin{array}{l}\text { Classical, } \mathrm{Sm}^{\mathrm{r}} \text { derivative } \\
\text { of strain } 0395\end{array}$ & This study \\
\hline $\operatorname{rec} A 1$ & $\begin{array}{l}\operatorname{rec} A \text { mutant of } \mathrm{KB} 207, \\
\mathrm{Sm}^{\mathrm{r}} \mathrm{Ap}^{\mathrm{r}}\end{array}$ & This study \\
\hline $\operatorname{rec} A 4$ & $\begin{array}{l}\operatorname{rec} A \text { mutant of } \mathrm{CD} 81 \\
\mathrm{Sm}^{\mathrm{r}}, \mathrm{Ap}^{\mathrm{r}}\end{array}$ & This study \\
\hline CD192 & $\begin{array}{l}\text { Classical, } \mathrm{Nal}^{\mathrm{r}} \\
\text { derivative of } \mathrm{KB} 92\end{array}$ & $\begin{array}{l}\text { This study } \\
\text { Srivastava et al. (1979) }\end{array}$ \\
\hline \multicolumn{3}{|l|}{ E. coli } \\
\hline SM10 $\lambda$ pir & $\begin{array}{l}\operatorname{rec} A \text { RP4-2TC: : Mu } \\
\mathrm{Km}^{\mathrm{r}} \text { thi thr leu suIII }\end{array}$ & Kolter et al. (1978) \\
\hline \multicolumn{3}{|l|}{ Plasmid } \\
\hline$P:: \operatorname{Tn} 1$ & $P$ factor, $A p^{r}$ & Khan et al. (1985) \\
\hline pGP704 & $\begin{array}{l}\text { Suicide cloning vector, } \\
A p^{r}\end{array}$ & $\begin{array}{l}\text { Miller \& Mekalanos } \\
\text { (1988) }\end{array}$ \\
\hline pCVD842 & $\begin{array}{l}\text { Mutant } \operatorname{rec} A \text { gene } \\
\text { cloned in } \mathrm{pBR} 322\end{array}$ & Ketley et al. (1990) \\
\hline pCVD845 & 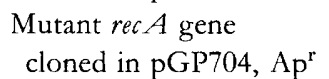 & This study \\
\hline
\end{tabular}

not kill the parent strain. Both irradiated and unirradiated plates were incubated in the dark at $37^{\circ} \mathrm{C}$. UV-sensitive colonies were picked from the unirradiated plate and further tested for MMS sensitivity. MMS sensitivity was tested on plates on which $2 \mu \mathrm{l}$ MMS (Sigma) suspended in $50 \mu \mathrm{l} \mathrm{L-broth} \mathrm{had} \mathrm{been} \mathrm{spread.}$

Southern analysis. A $2.5 \mathrm{~kb} \mathrm{Bg} / \mathrm{II}$ fragment containing the $\operatorname{rec} A$ gene of $V$. cholerae strain $569 \mathrm{~B}$ was labelled with $\alpha^{32} \mathrm{P}$ by the random primer method (Feinberg \& Vogelstein, 1983) and used as a probe for hybridization (Southern, 1975) under stringent conditions $\left(50 \%\right.$ formamide, $37^{\circ} \mathrm{C}, 750 \mathrm{mM} \mathrm{NaCl}$ washing at $65^{\circ} \mathrm{C}$ ). Total DNA was extracted from each strain by SDS lysis, proteinase $\mathrm{K}$ treatment, phenol/chloroform extraction and ethanol precipitation and digested with restriction endonucleases $B g / \mathrm{II}, K p n \mathrm{I}$ and $B g / \mathrm{II}+K p n \mathrm{I}$. After separation by agarose gel electrophoresis, Southern hybridization was performed with the probe mentioned above.

Adherence. Adherence of vibrios to rabbit intestinal discs were determined as previously described (Srivastava \& Srivastava, 1980 ; Jacob et al., 1993). Bacteria were grown overnight on Lagar slopes at $37^{\circ} \mathrm{C}$ and harvested in PBS. Bacteria were diluted to about $10^{7}$ cells $\mathrm{ml}^{-1}$ in $5 \mathrm{ml}$ PBS in which freshly isolated rabbit intestinal discs of $10 \mathrm{~mm}$ diameter were incubated for $30 \mathrm{~min}$. After two washings with $20 \mathrm{ml}$ PBS, the discs were homogenized and the number of adherent bacteria was determined by enumerating colony-forming units plated on antibiotic-containing selective media. The adherence index is the number of adherent vibrios expressed as a percentage of the total number of vibrios to which the disc of intact rabbit intestinal mucosa was exposed (Srivastava \& Srivastava, 1980).

Colonization. Colonization of vibrios was studied in 5-d-old suckling mice in two different ways, either by infection of mice with a single strain (Jacob et al., 1993) or infection in a competition assay with a mixture of both parent and isogenic $\operatorname{rec} A$ strains in equal numbers (Freter et al., 1981). In the competition assay, the mice were infected with $0.1 \mathrm{ml}$ inoculum that contained parent and $\operatorname{rec} A$ strains in approximately equal numbers.

Briefly, colonization was studied as follows. Bacterial dilutions containing $10^{7}$ vibrios $\mathrm{ml}^{-1}$ with $0.01 \%$ Evans blue dye were prepared and $0 \cdot 1 \mathrm{ml}$ was given orally to each mouse. Three mice were sacrificed each day from each group; their intestines were removed and homogenized in $10 \mathrm{ml}$ PBS, and viable counts were determined on antibiotic-containing selective agar media. For single infection studies, parent and rec $A$ strains were plated, respectively, on streptomycin-and ampicillin-containing plates. In double infections, plating on streptomycin gave total counts of both strains, whereas only $\operatorname{rec} A$ strains grew on ampicillin plates. The results of the competition assay are expressed as a competitive index, defined as the ratio of viable counts of the parent strain to that of the $\operatorname{rec} A$ mutant. Similarly, an in vitro competition assay was designed in which both strains were inoculated in L-broth at $37^{\circ} \mathrm{C}$ and the viable count of each strain was determined at intervals.

SDSPAGE and immunoblotting. SDS-PAGE $(12 \%, \mathrm{v} / \mathrm{v}$, polyacrylamide gels) was done as described previously (Studier, 1973; Hames, 1987; Jacob et al., 1993). Cultures were grown overnight in L-broth at $37^{\circ} \mathrm{C}$. A $0.2 \mathrm{ml}$ sample of the culture was collected by centrifugation, suspended in $0.2 \mathrm{ml}$ of SDSPAGE sample buffer, kept in a boiling water bath for $5 \mathrm{~min}$ and finally centrifuged for $5 \mathrm{~min}$ in a microfuge. A $20 \mu \mathrm{l} \mathrm{vol}$. of the supernatant was loaded in each lane of the gel. After electrophoresis, proteins were transferred by electroblotting onto nitrocellulose paper and detected by ELISA (Harlow \& Lane, 1988; Jacob et al., 1993). The source of primary antibody was rabbit anti-E. coli RecA IgG (obtained from Dr G. Barcak, University of Maryland at Baltimore) whereas the secondary antibody was goat anti-rabbit IgG coupled with alkaline phosphatase.

\section{RESULTS AND DISCUSSION}

\section{Construction and characterization of recA mutants}

We obtained recombination-deficient mutants of $V$. cholerae strains KB207 and CD81 by conjugal mating with E. coli SM10 2pir(pCVD845), which results in transfer of the mutated $\operatorname{rec} A$ gene present on pCVD845. The recombinants obtained in these bacterial crosses were scored on L-agar containing ampicillin and streptomycin. The Ap ${ }^{r}$ recombinants represent intermediate forms in which the whole plasmid is integrated into the chromosome through recombination in the $\operatorname{rec} A$ region: they carry a wild-type and a mutant copy of the $\operatorname{rec} A$ gene. When $A^{r}{ }^{r}$ recombinants were grown and tested for $A \mathrm{p}^{\mathrm{s}}$ derivatives lacking the integrated plasmid, none were obtained in more than 5000 colonies screened. Ap ${ }^{r}$ recombinants were therefore screened for $\operatorname{rec} A$ mutants by testing UV and MMS sensitivities. Of the $\mathrm{Ap}^{\mathrm{r}}$ recombinants, $0 \cdot 1-0 \cdot 3 \%$ were phenotypically $\operatorname{Rec}^{-}$. Two such strains (rec $A 1$ and $\operatorname{rec} A 4)$ were selected for further study.

The survival of $\operatorname{rec} A$ and parent strains at a single UV dose is given in Table 2 . The survival of $\operatorname{rec} A$ strains was 
Table 2. UV sensitivity and frequency of recombination of the parent and recA strains

\begin{tabular}{|c|c|c|}
\hline Strain & $\begin{array}{c}\text { Survival (\%) } \\
\text { at a } \mathrm{UV} \text { dose } \\
\text { of } 5 \mathrm{~J} \mathrm{~m}^{-2}\end{array}$ & $\begin{array}{l}10^{-7} \times \\
\text { No. of Nal } \\
\text { recombinants }\end{array}$ \\
\hline $\mathrm{KB} 207$ & 5 & 54 \\
\hline $\operatorname{rec} A 1$ & $0 \cdot 01$ & 0 \\
\hline CD81 & 1 & 195 \\
\hline $\operatorname{rec} A 4$ & 0.0035 & 3 \\
\hline
\end{tabular}

found to be less than isogenic parent strains. The efficiency of homologous recombination of $\operatorname{rec} A$ mutants was determined in P-factor-mediated transfer of a $\mathrm{Nal}^{\mathrm{r}}$ marker (Khan et al., 1985; Goldberg \& Mekalanos, 1986a). Both rec. $A$ and parent strains were mated with CD192(P::Tn1) and $\mathrm{Nal}^{\mathrm{r}}$ recombinants were selected in media containing nalidixic acid $\left(2 \mu \mathrm{g} \mathrm{ml}^{-1}\right)$ and streptomycin. As shown in Table 2, a higher frequency of recombination was observed with parent than with $\operatorname{rec} A$ strains. The $\operatorname{rec} A$ mutants are, therefore, greatly reduced in homologous recombination. Thus, the $\operatorname{rec} A$ mutants isolated in this study exhibit the same characteristics described for $\operatorname{rec} A$ mutants of E. coli (Clark, 1973) and $V$. cholerae (Goldberg $\&$ Mekalanos, 1986a). When parent and $\operatorname{rec} A$ strains were probed with antibodies to $E$. coli RecA protein by immunoblotting, $\operatorname{rec} A$ strains were found to lack $\operatorname{Rec} A$ protein which was prominently in the parent strains (Fig. 1). The size of the RecA protein of KB207 and CD81 corresponds to the size reported for $V$. cholerae and E. coli (Paul et al., 1986).

To explain the Rec $\mathrm{A}^{-}$phenotype of the $\mathrm{Ap}^{\mathrm{r}}$ derivatives, the genotypes of the $\operatorname{rec} A 1$ and $\operatorname{rec} A 4$ mutants were investigated by Southern blot analysis using as probe a $2.5 \mathrm{~kb} \mathrm{Bg} / \mathrm{II}$ fragment containing the $\operatorname{rec} A$ gene of $V$. cholerae (Fig. 2). When the parent strains KB207 and CD81 were digested with $B g / I \mathrm{I}$ and $B g / \mathrm{II}+K p n \mathrm{I}$, the probe annealed to a $2.5 \mathrm{~kb}$ fragment, indicating that wild-type rec $A$ lacks a KpnI site (Fig. 2, lanes A-C). The pattern obtained with the $\operatorname{rec} A 4$ mutant indicates that it contains only mutant copies of the $\operatorname{rec} A$ gene, since $B g / \mathrm{II}+K p n \mathrm{I}$ digestion generated a $2 \mathrm{~kb}$ fragment. In contrast, double digestion of the $\operatorname{rec} A 1$ mutant generated two fragments of 2.5 and $2.0 \mathrm{~kb}$, which is consistent with this strain containing one wild-type and one mutant copy of the $\operatorname{rec} A$ gene. However, since the rec $A 1$ mutant did not synthesize RecA protein (Fig. 1) we concluded that the wild-type copy of the gene is not functional.

The suicide vector pCVD845, to which a mutant $\operatorname{rec} A$ gene was ligated, required the pir gene product of $\lambda$ for autonomous replication and could not replicate in $V$. cholerae. Selection of $A p^{r}$ transconjugants required integration of the plasmid into the chromosome, an event that takes place through homologous recombination at the site of the $\operatorname{rec} A$ gene. The $\operatorname{rec} A 1$ mutation is probably due to a disruption of the wild-type $\operatorname{rec} A$ gene in the chromosome as a result of integration.

\section{Adherence and colonization studies}

Adherence of strains $\mathrm{KB} 207$ and $\mathrm{CD} 81$ and their $\operatorname{rec} A$ derivatives to rabbit intestine was measured. The adherence of parent strains was higher than that of $\operatorname{rec} A$ mutants. The $\operatorname{rec} A$ mutation caused about $65 \%$ decrease in adherence (Table 3). To assess the effect of $\operatorname{rec} A$ mutation on colonization of intestine by parent and $\operatorname{rec} A$ strains, survival of bacteria in the intestine of infant mice was determined. Results of an experiment in which mice were infected with a single strain and followed for up to $72 \mathrm{~h}$ are shown in Fig. 3. It was found that the $\operatorname{rec} A$ mutants did not colonize the intestine as efficiently as the parent strains. KB207 persisted in the gut in high numbers up to $72 \mathrm{~h}$ following infection whereas cell numbers for the isogenic $\operatorname{rec} A$ derivative were 1000 -fold fewer. The $\operatorname{rec} A 4$ mutant of $\mathrm{CD} 81$ was eliminated from the gut in $24 \mathrm{~h}$, whereas CD81 colonized the gut with resulting high viable counts up to $72 \mathrm{~h}$. The results obtained from this

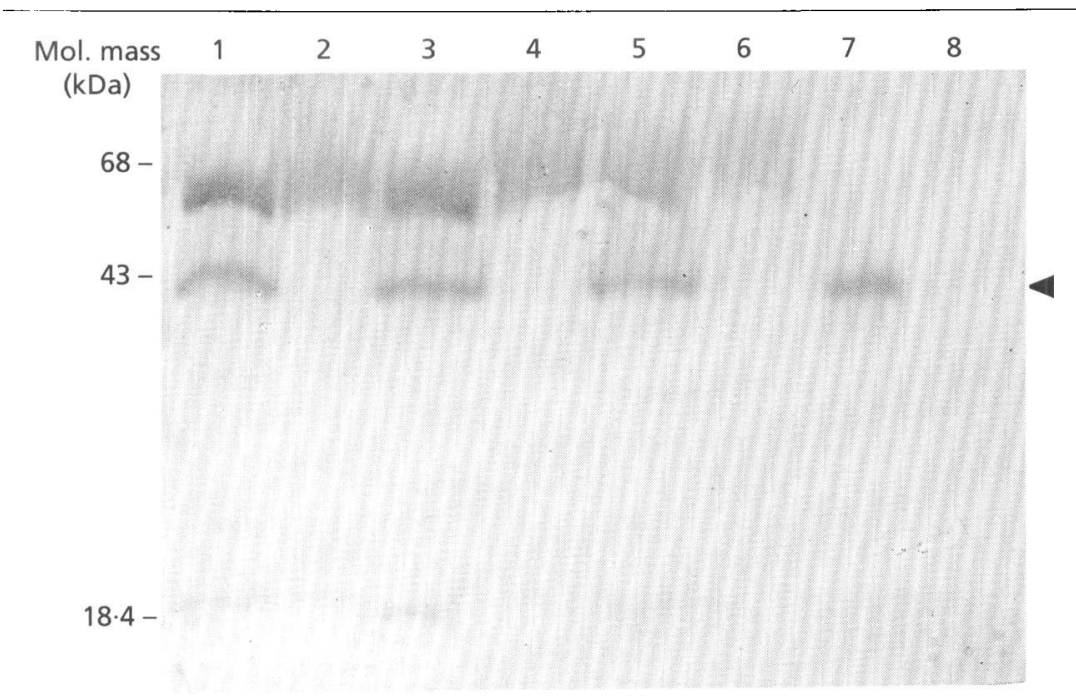

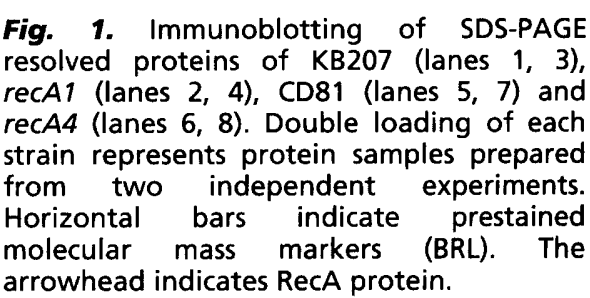

Fig. 1. Immunoblotting of SDS-PAGE resolved proteins of KB207 (lanes 1, 3), recA1 (lanes 2, 4), CD81 (lanes 5, 7) and strain represents protein samples prepared from two independent experiments. Horizontal bars indicate prestained arrowhead indicates RecA protein. 


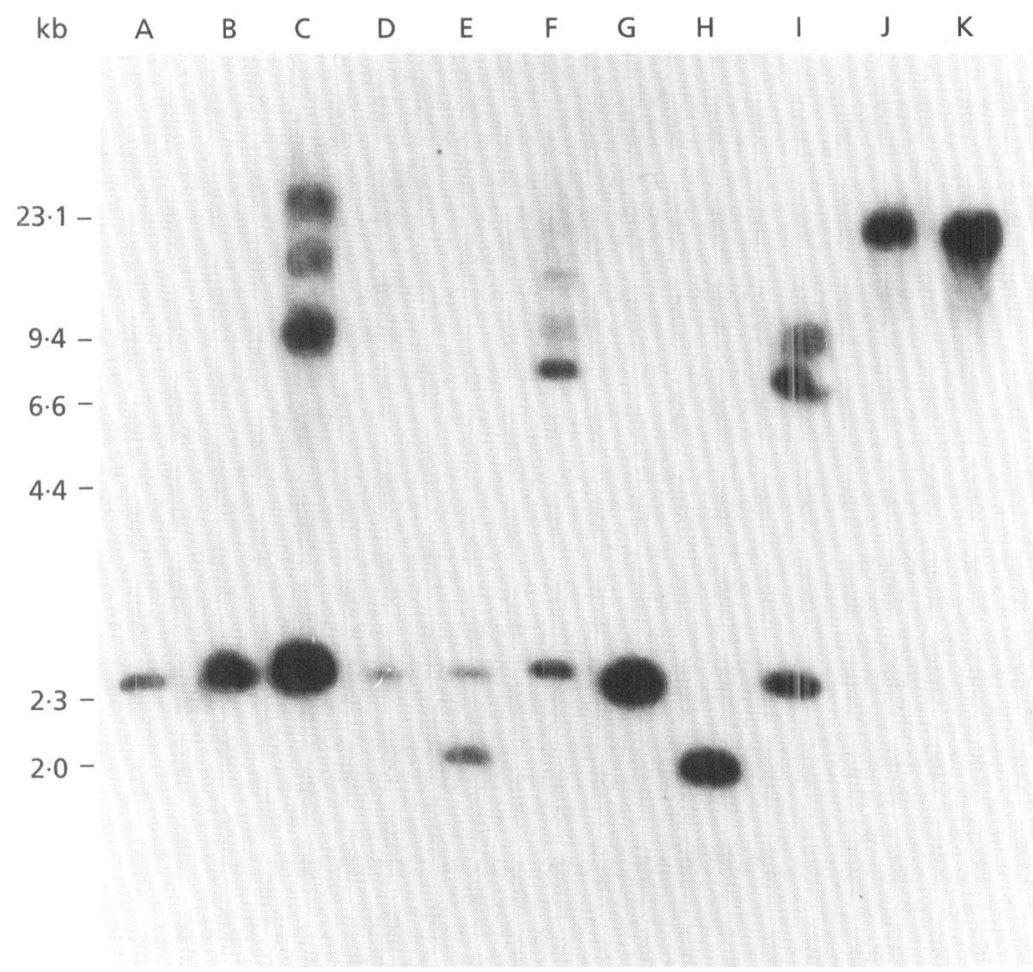
Fig. 2. Southern blot analysis of restriction endonuclease digested genomic DNA of the parent and recA mutant strains. Lanes: $A$, KB207 Bg/lI + Kpnl; B, CD81 Bg/ll; C, CD81 $B g / l l+K p n l ; \quad D$, recA1 Bg/ll; E, recA1 $B g / l \mathrm{I}+$ Kpnl; $\mathrm{F}$, recA1 Kpnl; G, recA4 Bg/lI; $\mathrm{H}$, recA4 Bg/ll + Kpnl; l, recA4 Kpnl; J, KB207 Kpnl; K, CD81 Kpnl. Horizontal bars indicate HindIII-digested $\lambda$ DNA molecular size markers.

Table 3. Adherence and competitive index of the parent and $r e c A$ strains

\begin{tabular}{|lccc|}
\hline Strain & $\begin{array}{c}\text { Adherence } \\
\text { index } \\
\pm \mathbf{S E}\end{array}$ & \multicolumn{2}{c|}{$\begin{array}{c}\text { Competitive index } \\
\pm \mathbf{S E}\end{array}$} \\
\cline { 3 - 4 } & & $24 \mathbf{h}$ & $48 \mathbf{h}$ \\
\hline $\mathrm{KB} 207$ & $2 \cdot 95 \pm 0 \cdot 187$ & $15 \pm 0.115$ & $60 \pm 1.73$ \\
$\mathrm{rec} A 1$ & $1.01 \pm 0.109$ & & \\
$\mathrm{CD} 81$ & $1.67 \pm 0.086$ & $250 \pm 6.99$ & $>2000$ \\
$\operatorname{rec} A 4$ & $0.58 \pm 0.058$ & & \\
\hline
\end{tabular}

Data are from a representative experiment; variation among similar experiments was $<10 \% ; P<0.01$. Adherence index is the number of adherent vibrios expressed as percentage of the total number of vibrios to which the discs of intact rabbit intestinal mucosa were exposed. Competitive index is the ratio of viable counts of the parent strain to that of the $\operatorname{rec} A$ mutant.

experiment suggested that the colonizing ability of $V$. cholerae was significantly reduced by $\operatorname{rec} A$ mutation. A similar conclusion could be drawn from an experiment in which mice were infected with both parent and $\operatorname{rec} A$ strains. The results of this competition assay are given in Table 3. The competitive index increased with time, suggesting a greater rate of elimination of $\operatorname{rec} A$ mutants. The reduced colonization by $\operatorname{rec} A$ mutants was not due to differences in the growth rates of parent and mutant strains. In an in vitro competition assay in which parent and isogenic $\operatorname{rec} A$ strains were grown together, the competitive index was only $2-4$ (data not shown). Within
$6 \mathrm{~h}$, cultures were saturated and both strains were nearly equal in viable counts.

These results suggest that $\operatorname{rec} A$ plays a significant role in colonization and adherence of $V$. cholerae in animal intestine. Indeed, a recombination-deficient derivative of a $V$. cholerae vaccine strain was found to be less immunogenic in volunteer studies. On the basis of positive stool cultures, this effect was attributed to diminished colonization by the $\operatorname{rec} A$ vaccine strain as compared to the rec $A^{+}$vaccine strain (Ketley et al., 1990). The mechanism by which $\operatorname{rec} A$ affects adherence and colonization of $V$. cholerae in the intestine is not known.

In $E$. coli, a functional $\operatorname{rec} A$ gene has been shown to have a number of cellular functions, namely homologous recombination (Clark, 1973) and repair of DNA damage induced by radiation, chemical agents and non-physiological growth conditions (Howard-Flanders, 1968; Bridges et al., 1969). It is possible that a functional $\mathrm{rec} A$ gene might be required by $V$. cholerae to overcome deleterious environmental conditions in the intestinal tract.

In $V$. cholerae, it has been reported that the $\operatorname{rec} A$ gene is required in DNA rearrangements leading to the amplification of cholera toxin structural genes (Goldberg \& Mekalanos, 1986b). Since amplification of ctx genetic element in vivo could enhance pathogenicity of $V$. cholerae, a mutation in $\operatorname{rec} A$ would reduce the virulence of $V$. cholerae. It may be speculated that the $\operatorname{rec} A$ mutation might affect expression of colonizing factors. Little is known about factors involved in adherence and colonization of $V$. cholerae and regulation of expression of these factors in vivo. Toxin-coregulated pili (Taylor et al., 1987), fimbriae (Hall et al., 1988), accessory colonization factors (Peterson 


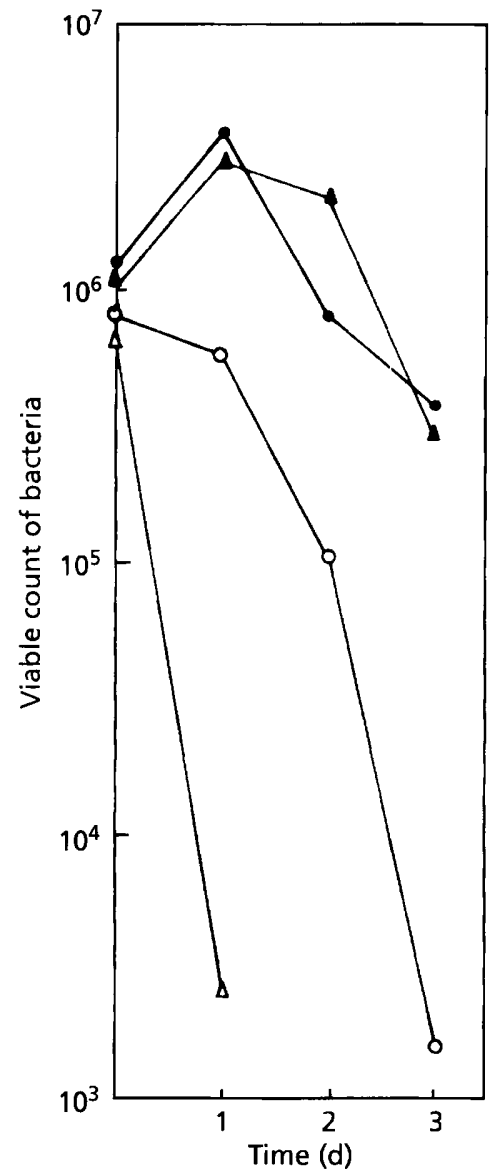

Fig. 3. Non-competitive colonization of infant mice $\mathrm{O}, \mathrm{rec} A 1 ; \Delta, \mathrm{CD} 81 ; \triangle$, recA4.

\& Mekalanos, 1988) and a $33 \mathrm{kDa}$ protein antigen (Jacob et al., 1993) with a possible role in adherence and/or colonization of $V$. cholerae have been reported. Of these, the toxin-coregulated pilus is the most extensively studied colonization factor, expression is linked to toxin biosynthesis under the control of the Tox R regulon. Therefore, the molecular mechanism governing the effect of RecA on vital steps in the pathogenesis of cholera, namely adherence, colonization and toxin production is of fundamental interest.

The results reported here and previously (Ketley et al., 1990; (ioldberg \& Mekalanos, 1986b) on the possible role of the $\operatorname{rec} A$ gene suggest that a recombination-deficient strain may have positive as well as negative applications in the development of a cholera vaccine. While a $\operatorname{rec} A$ mutation may enhance the safety of a vaccine strain, it would, on the other hand, diminish adherence and colonization in the intestine.

\section{ACKNOWLEDGEMENTS}

Indian investigators are grateful to the Director of the Institute for facilities and to $\mathrm{Mr} \mathrm{M}$. U. Khan for technical assistance. We thank Dr Gerard Barcak for providing rabbit anti-RecA antibodies. This work was supported by a grant from INDOUS Vaccine Action Program to J.B.K. and B.S.S. This is communication no. 5065 of CDRI.

\section{REFERENCES}

Bridges, B. A., Ashwood-Smith, M. J. \& Munson, R. J. (1969). Correlation of bacterial sensitivities to ionizing radiation and mild heating. J Gen Microbiol 58, 115-124.

Clark, A. J. (1973). Recombination deficient mutants of E. coli and other bacteria. Annu Rev Genet 7, 67-86.

Feinberg, A. P. \& Vogelstein, B. (1983). A technique for radiolabeling DNA restriction endonuclease fragments to high specific activity. Anal Biochem 132, 6-13.

Freter, R., O'Brien, P. C. M. \& Macsai, M. M. S. (1981). Role of chemotaxis in the association of motile bacteria with intestinal mucosa; in vivo studies. Infect Immun 34, 234-240.

Ghosh, R. K., Siddiqui, K. A. I., Mukopadhyay, G. \& Ghosh, A. (1985). Evidence that a system similar to the rec $A$ system of Escherichia coli exists in Vibrio cholerae. Mol \& Gen Genet 200, 439-441.

Goldberg, I. \& Mekalanos, J. J. (1986a). Cloning of the Librio cholerae rec $A$ gene and construction of a Vibrio cholerae rec 1 mutant. $J$ Bacteriol 165, 715-722.

Goldberg, I. \& Mekalanos, J. J. (1986b). Effect of a rec $A$ mutation on cholera toxin gene amplification and deletion event. J Bacteriol 165, 723-731.

Hall, R. H., Vial, P. A., Kaper, J. B., Mekalanos, J. J. \& Levine, M. M. (1988). Morphological studies on fimbriae expressed by Vibrio cholerae O1. Microb Pathog 4, 257-265.

Hames, B. D. (1987). An introduction to polyacrylamide gel electrophoresis. In Gel Electrophoresis of Proteins, pp. 1-86. Edited by B. D. Hames \& D. Rickwood. Oxford: IRL Press.

Harlow, E. \& Lane, D. (1988). Antibodies, pp. 283-612. Cold Spring Harbor, NY: Cold Spring Harbor Laboratory.

Howard-Flanders, P. (1968). DNA repair. Annu Rev Biochem 37, 175-200.

Jacob, A., Sinha, V. B., Sahib, M. K., Srivastava, R., Kaper, J. B. \& Srivastava, B. S. (1993). Identification of a $33 \mathrm{kDa}$ antigen associated with an adhesive and colonizing strain of Vibrio cholerae el tor and its role in protection. Laccine 11, 376-382.

Ketley, J. M., Kaper, J. B., Harrington, D. A., Losonsky, G. \& Levine, M. M. (1990). Diminished immunogenicity of recombinant deficient derivative of $V$ ibrio cholerae vaccine strain CVD103. Infect Immun 58, 1481 - 1484.

Khan, A. A., Srivastava, R., Sinha, V. B. \& Srivastava, B. S. (1985). Regulation of toxin biosynthesis by plasmids in I'ibrio cholerae. J Gen Microbiol 131, 2653-2657.

Kolter, R., Inuzuka, M. \& Helinski, D. R. (1978). Trans-complementation-dependent replication of a low molecular weight origin fragment from plasmid R6K. Cell 15, 11991208.

Mekalanos, J. J. (1983). Duplication and amplification of toxin genes in Vibrio cholerae. Cell 35, 253-263.

Miller, V. L. \& Mekalanos, J. J. (1988). A novel suicide vector and its use in construction of insertion mutations: osmoregulation of outer membrane proteins and virulence determinants in I'ibrio cholerae requires toxR. J Bacteriol 170, 2575-2583.

Paul, K., Ghosh, S. K. \& Das, J. (1986). Cloning and expression of Escherichia coli rec $A$ like gene from Vibrio cholerae. Mol \& Gen Genet 203, 58-63.

Peterson, K. M. \& Mekalanos, J. J. (1988). Characterization of the 
Vibrio cholerae 'ToxR regulation: Identification of novel genes involved in intestinal colonization. Infect Immun 56, 2822-2829.

Simon, R., Priefer, U. \& Puhler, A. (1983). A broad host range mobilization system for in vivo genetic engineering: transposon mutagenesis in Gram negative bacteria. Bio/Tecbnology 1, 784-791.

Southern, E. M. (1975). Detection of specific sequences among DNA fragments separated by gel electrophoresis. J Mol Biol 98, 503-517.

Srivastava, R. \& Srivastava, B. S. (1980). Isolation of a nonadhesive mutant of Vibrio cholerae and chromosomal localization of the gene controlling mannose-sensitive adherence. J Gen Microbiol $117,275-278$.
Srivastava, B. S., Sinha, V. B. \& Srivastava, R. (1979). Attenuated recombinant strains of Vibrio cholerae for oral immunization. Bull WHO 57, 649-654.

Studier, F. W. (1973). Analysis of bacteriophage T7 early RNAs and proteins on slab gels. $J$ Mol Biol 79, 237-248.

Taylor, R. K., Miller, V. L., Furlong, D. B. \& Mekalanos, J. J. (1987). Use of $p h o A$ gene fusions to identify a pilus colonization factor coordinately regulated with cholera toxin. Proc Natl Acad Sci USA 84, 2833-2837.

Received 26 October 1993; accepted 24 November 1993. 